\title{
Estudo macroscópico e histológico de reparos osteocondrais biologicamente aceitáveis.
}

\author{
Macroscopic and histological study of biologically acceptable osteochondral repairs.
}

\author{
José LeÃo Ribeiro', Gillberto luis Camanho², Luiz Carlos Takita ${ }^{3}$
}

\section{RESUMO}

Este estudo teve como finalidade avaliar macroscopicamente e histológicamente defeitos osteocondrais já cicatrizados, também conhecidos como reparos. Foram utilizados seis coelhos machos, adultos, albinos da raça Nova Zelândia. Defeitos cilíndricos osteocondrais de $3.2 \mathrm{~mm}$ de diâmetro por $4.0 \mathrm{~mm}$ de profundidade foram criados cirurgicamente em ambos côndilos femorais mediais. O cilindro osteocondral retirado do joelho esquerdo (defeito não tratado) foi implantado no joelho direito (joelho tratado). Comparou-se macroscopicamente e histológicamente ambos tipos de defeitos após doze semanas de evolução. A avaliação macroscópica de todos os defeitos mostrou evolução para reparos denominados biologicamente aceitáveis. O termo "biologicamente aceitável" foi utilizado para definir reparos, que à observação macroscópica, se apresentaram como tecido neo-formado semelhante à fibrocartilagem, brilhante, liso, firme, em continuidade com a cartilagem adjacente. Como todos os defeitos, tratados e não tratados, eram macroscopicamente semeIhantes, realizou-se um estudo histológico comparativo para averiguar qual tipo de tecido de reparação se formava em ambos defeitos. Pela análise histológica dos reparos biologicamente aceitáveis, concluiu-se que houve formação de tecido cartilaginoso hialino nos defeitos tratados com enxerto autólogo e de tecido fibrocartilaginoso nos defeitos não tratados

Descritores: Joelho; Transplante autólogo; Cartilagem articular; Defeito osteocondral; Coelho

\section{INTRODUÇÃO}

O tratamento cirúrgico das lesões condrais e osteocondrais que acometem articulações que suportam carga, principalmente o joeIho, ainda representa um desafio para o ortopedista. Isto se deve às características da cartilagem hialina articular, que por ser desprovida de vascularização tem limitado potencial de cicatrização.

De acordo com Mankim(15), a cicatrização de uma lesão restrita à cartilagem hialina articular (defeito condral), não obedece inteiramente às três fases naturais que são a necrose, inflamação e reparação, justamente por causa da sua condição avascular.

Como em qualquer outro tecido corpóreo lesado, existe a mesma fase de necrose inicial e conseqüentemente ocorre a perda celular e da matriz. Como os condrócitos são relativamente insensíveis à condição de hipóxia instalada, existe um número menor de células

Trabalho realizado no Serviço de Ortopedia do Departamento de Clinica Cirúrgica da Universidade Federal de Mato Grosso.

1 - Professor Adjunto de Ortopedia da Universidade Federal de Mato Grosso

2 - Professor Associado da Faculdade de Medicina da Universidade de São Paulo - FMUSP

3 - Professor Assistente de Anatomia Patológica Especial da Universidade Federal de Mato Grosso do Sul

Endereço para correspondência: R. Osório Duque Estrada, 15 - Hospital Ortopédico, CEP -78005-720, Cuiabá-MT, e-mail: drleao@terra.com.br

Trabalho recebido em 21/05/03. Aprovado em 16/02/04.

\section{SUMMARY}

The aim of this study was to evaluate macroscopically and histologically healed osteochondral defects, also known as repairs. Six adult, male, New Zealander White rabbits were used. Cylindrical osteochondral defects of $3.2 \mathrm{~mm}$ in diameter by $4.0 \mathrm{~mm}$ in depth were artificially created in the load-bearing surfaces of both medial femoral condyles. The osteochondral graft collected from the left knee (untreated defect) was implanted in the right knee (treated defect). Both defects were compared macroscopically ad histologically after twelve weeks. The macroscopic evaluation of all defects demostrated evolution in repairs called "biologically acceptable". The "biologically acceptable" term was used to define repairs, that at macrocospic observation, presented as neo-formed tissue similar to fibrocartilage, brilliant, smooth, firm, in continuity with the adjacent cartilage. As all the defects, treated and untreated, were macroscopically similar, a histological comparative study was made to verify which type of repair tissue was formed in the surface of both defects. By histologic analysis of the biologically acceptable repairs, the authors conclude that: treated defects with autologous grafts were filled with hyaline cartilaginous tissue and untreated defects were filled with fibrocartilaginous tissue.

Key words: Knee; Autologous transplantation; Articular cartilage; Osteochondral defect; Rabbit

\section{INTRODUCTION}

The surgical treatment of the chondral and osteochondral injuries that affect articulations that support load, mainly the knee, still represents a challenge for the orthopedist. This is due to the characteristics of the articular hyaline cartilage, that is unprovided of vascularization and so has limited potential of cicatrization. According to Mankim ${ }^{(15)}$ the cicatrization of an injury restricted to the articular hyaline cartilage (chondral defect) doesn't follow the three natural phases - the necrosis, the inflammation and the repair - exactly because of its avascular condition. As in any other injured body tissue, the same phase of initial necrosis occurs and consequently there is loss of cells and matrix. As the chondrocytes are relatively insensitive to the condition of installed hypoxia; there is a smaller number of dead cells than in any other organical tissue. A second phase of inflammation, as is entirely mediated for the vascular system, is absent. Consequently, the hematoma formation doesn't occur, and so it does not produce fibrin or coagulum of fibrin that would work as a frame for the new repair tissue growth.

Work performed at the Orthopedics Service of the Surgical Clinica Department of the Universidade Federal de Mato Grosso

1 - Adjuct Professor of Orthopedics of the Universidade Federal de Mato Grosso

2 - Associate Professor of the Universidade de São Paulo - FMUSP 3 - Assistant Professor of Special Pathological Anatomy of the Universidade Federal de Mato Grosso do Sul

Mail address: R. Osório Duque Estrada, 15 - Hospital Ortopédico, CEP 78005-720, Cuiabá-MT, e-mail: drleao@terra.com.br 
mortas do que em qualquer outro tecido orgânico. A segunda fase de inflamação por estar inteiramente mediada pelo sistema vascular é ausente, conseqüentemente não há formação de hematoma, não há produção de fibrina e nem de coágulo de fibrina que serviria como arcabouço para o novo tecido de reparação que iria crescer, não havendo conseqüentemente continuidade do processo. Considerando a terceira fase que é a reparação, a ausência de uma fase vascular ou inflamatória limita consideravelmente o número de células disponíveis para responder ao trauma e a capacidade de reparo falha nos condrócitos remanescente o que termina por bloquear definitivamente o processo de cicatrização.

No entanto é reconhecido que se a lesão se estende até o osso subcondral (defeito osteocondral), muito bem vascularizado, todas as três fases ocorrem naturalmente $\mathrm{e}^{(3,5,11,15)}$. O hematoma rapidamente se organiza com coágulos de fibrina, glóbulos brancos e elementos da medula óssea. Células indiferenciadas da medula e endotélio vascular são transformadas em fibroblastos primitivos que com o aporte de capilares e coágulos de fibrina se transformam em tecido fibroblástico vascularizado de reparação(15)

O estudo da cicatrização das lesões cartilaginosas tem sido efetuado em diversos modelos experimentais animais. Provavelmente nenhum outro experimento tenha sido executado tão freqüentemente, quando se trata de estudo sobre cartilagem, quanto a lesão cirúrgica experimental e a observação do comportamento da cartilagem do ponto vista macroscópico, radiológico, bioquímico, biomecânico, biomolecular e ultraestrutural $(3,4,7,15)$.

As lesões focais da cartilagem articular requerem tratamento cirúrgico que vão desde métodos clássicos de estimulação da medula óssea como desbridamento, perfurações múltiplas, abrasões, microfraturas $^{(12,19,22,23)}$, até métodos biológicos modernos como transplantes periosteais e pericondriais, implante de condrócitos autólogos cultivados, e enxertos autólogos osteocondrais ${ }^{(1,9,17,18,21)}$. Por causa do alto custo e de restrições técnicas impostas a vários métodos biológicos de tratamento das lesões osteocondrais, alguns autores buscaram métodos também eficazes, porem de maior facilidade de execução. Um desses métodos simples e direto é sem dúvida o transplante ou enxerto autólogo osteocondral que representa uma boa alternativa para reparação biológica da lesão focal da superfície articular. Consiste em preencher o defeito com cilindro osteocondral único, ou conforme o tamanho da lesão, com uma série de pequenos enxertos osteocondrais, técnica que ficou conhecida como mosaicoplastia. Foi utilizada em cães, cavalos e cadáveres humanos por Hangody ${ }^{(9)}$ desde 1991 e as áreas doadoras e receptoras foram estudadas para verificação do comportamento das lesões e sobrevida da cartilagem hialina transplantada.

Este modelo experimental teve como base o método de tratamento das lesões osteocondrais descrito e desenvolvido por Hango$d y^{(9)}$. Optou-se por provocar cirurgicamente defeitos osteocondrais em ambos côndilos femorais de coelhos. O defeito do joelho direito (D) foi preenchido por enxerto osteocondral autólogo (tratado) e o defeito do joelho esquerdo (E) permaneceu vazio (não tratado).

O objetivo deste estudo foi comparar macroscopicamente e histológicamente os defeitos osteocondrais cicatrizados após doze semanas de evolução.

\section{MATERIAL E MÉTODOS}

\section{1 - Animais de experimentação}

Para o estudo proposto foram utilizados seis coelhos machos, albinos, adultos da raça Nova Zelândia pesando entre $3.4 \mathrm{~kg}$ e $3.6 \mathrm{~kg}$. Os animais foram alojados em sala apropriada e confinados em gaiolas metálicas medindo 70X70X70, alimentados com ração padrão peletizada e água ad libitum.
This way there isn't continuity in this process. Considering the third phase that is the repair, the absence of a vascular or inflammatory phase limits the number of available cells to respond to the trauma and the repair capacity fails in the remaining chondrocytes, blocking the cicatrization process definitively.

However it is known that if the injury extends until the subchondral bone (osteochondral defect), that is well vascularized, all the three phases occur naturally(3,5,11,15). The hematoma is quickly organized with coagulum of fibrin, white globules and elements of the bone marrow. Undifferentiated cells of the marrow and vascular endothelium are transformed into primitive fibroblasts and become fibroblastic vascularized tissues of repair by receiving capillaries and coagulum of fibrin ${ }^{(15)}$. The study of the cicatrization of the cartilaginous injuries has been performed in diverse animal experimental models. Probably, no other experiment has been so frequently performed, concerning the study of cartilage, experimental surgical injury and the observation of the cartilage behavior by macroscopical, radiological, biochemical, biomechanic, biomolecular and ultrastructural view ${ }^{(3,4,7,15)}$. The focal injuries of the articular cartilage require surgical treatment that includes the classic methods of stimulation of the bone marrow such as debridement, multiple perforations, abrasions, microfractures ${ }^{(12,19,22,23)}$, and modern biological methods such as periosteal and perichondral transplants, implantation of cultivated autologous chondrocytes, and autologous osteochondral grafts ${ }^{(1,9,17,18,21)}$. Because of the high cost and technical restrictions imposed to some biological methods of treatment of the osteochondral injuries, some authors have also searched efficient methods and easier to perform.

One of these simple and direct methods is the transplant or autologous osteochondral graft that represents a good alternative for biological repair of the focal injury of the articular surface. It consists of filling the defect with a unique osteochondral cylinder, or according to the size of the injury, with a series of small osteochondral grafts. This technique is known as mosaicplasty. It has been used in dogs, horses and human corpses by Hangody ${ }^{(9)}$ since 1991 and the donor and receiver portions have been studied in order to verify the injuries behavior and supervene of the transplanted hyaline cartilage.

The method of treatment of the osteochondral injuries described and developed by Hangody ${ }^{(9)}$ was the base for this experimental model. Osteochondral defects in both femoral condyles of rabbits were surgically produced. The defect of the right knee (D) was filled by autologous osteochondral graft (treated) and the defect of the left knee (E) remained empty (untreated). The aim of this study was to compare macroscopically and histologically the osteochondral defects healed after twelve weeks of evolution.

\section{MATERIAL AND METHOD}

\section{1 - Animals of experimentation}

Six male, albinic, adult rabbits of the New Zealander race, weight between $3.4 \mathrm{~kg}$ and 3,6 kg were used in this study. The animals were lodged in appropriate room and confined in metallic cages measuring 70X70X70. They were fed with standard pelleted ration and water ad libitum.

\section{2 - Surgical technique}

As a pre-anesthetical drug, each animal received $0,2 \mathrm{mg} / \mathrm{kg}$ of weight of acepromazine $1 \%$ by intramuscular. The anesthesia consisted of the intramuscular application of hydrochloride of ketamine $5 \%$ in the dose of $50 \mathrm{mg} / \mathrm{kg}$ of weight associated with xylazine $2 \%$ with the dose of $3 \mathrm{mg} / \mathrm{kg}$ of weight.

After the trichotomy of the surgical area it was performed a parapatellar medial incision followed by arthrotomy and lateral dislocation of patella. 


\section{2 - Técnica cirúrgica}

Como droga pré-anestésica cada animal recebeu $0.2 \mathrm{mg} / \mathrm{kg}$ de peso de acepromazina $1 \%$ via intramuscular. $A$ anestesia constou da aplicação por via intramuscular de cloridrato de ketamina $5 \%$ na dose de $50 \mathrm{mg} / \mathrm{kg}$ de peso associada a xilazina $2 \%$ na dose de $3 \mathrm{mg} / \mathrm{kg}$ de peso.

Após tricotomia da área cirúrgica realizou-se incisão parapatelar medial seguida de artrotomia e luxação lateral da patela. Com o joelho fletido expôsse o côndilo femoral medial e com auxílio de trefina metálica retirou-se um cilindro osteocondral de $3.2 \mathrm{~mm} / 4.0 \mathrm{~mm}$ do joelho E (Figura 1). Através de perfurações seqüenciais com brocas até $3.2 \mathrm{~mm}$ criou-se o defeito osteocondral no joelho $D$.

O enxerto osteocondral retirado do joelho $E$ (defeito não tratado) foi então transferido para o joelho D (defeito tratado) (Figura 2). Procedeu-se a síntese das feridas operatórias e os animais foram devolvidos às suas respectivas gaiolas para recuperação pós-operatória.

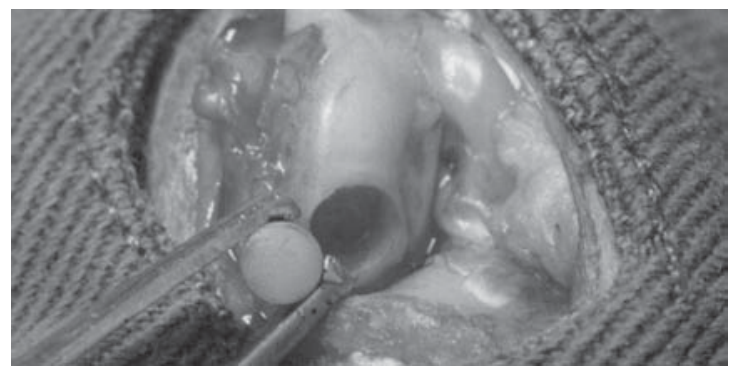

Figura 1 - Enxerto osteocondral retirado do joelho esquerdo - defeito não tratado.

Figure 1 - Osteochondral graft removed from left knee untreated defect.

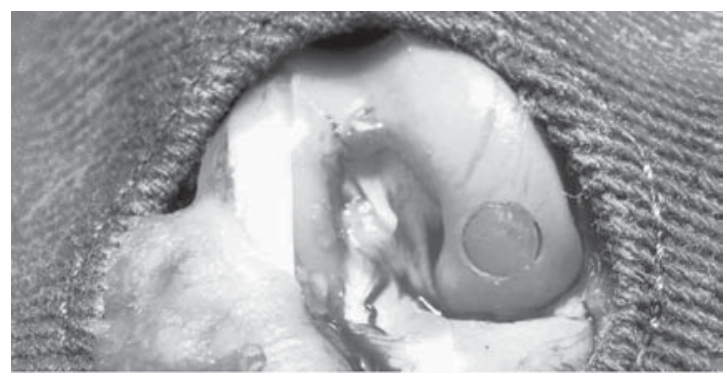

Figura 2 - Enxerto osteocondral retirado do joelho direito defeito tratado.

Figure 2 - Osteochondral graft removed from right knee treated defect.
As the knee was flexed, the femoral medial condyle was exposed and with the help of a metallic trephine an osteochondral cylinder of $3.2 \mathrm{~mm} / 4.0 \mathrm{~mm}$ was removed from the knee $E$ (Figure 1). Through sequential perforations with up to 3.2- $\mathrm{mm}$ drills, the osteochondral defect in knee $D$ was created.

Osteochondral grafts removed from knee $E$ (untreated defect) were then transferred to knee $D$ (treated defect) (Figure 2). The synthesis of the surgical wounds was performed and the animals returned to their respective cages for postoperative recovery.

\section{3 - Euthanasia}

It was performed in the animals after 90 days of evolution by a similar anesthesia used in the preoperative, followed by endovenous injection of $60 \mathrm{mg} /$ $\mathrm{kg}$ of potassium chloride.

Both knees were removed in order to be carefully examined. All the data of the macroscopic evaluation of the obtained repairs were noted. The parts then were led to histologic study.

\section{3 - Eutanásia}

Foi realizada nos animais aos 90 dias de evolução com anestesia similar à do pré-operatório, seguida de injeção endovenosa de 60 $\mathrm{mg} / \mathrm{kg}$ de cloreto de potássio.

Foram retirados ambos joelhos, examinados cuidadosamente para anotação dos dados da avaliação macroscópica dos reparos obtidos. As peças foram então encaminhadas para estudo histológico.

\section{4 - Critérios de avaliação}

Considerou-se especificamente para o estudo proposto a análise de dois critérios de avaliação: macroscópico e histológico.

\section{1 - Avaliação macroscópica}

Analisou-se através da inspeção macroscópica cinco parâmetros: a reparação diz respeito a cicatrização propriamente dita do defeito, a continuidade é a nivelação e integração do reparo com a cartilagem adjacente. Os outros três parâmetros mostram as características externas do reparo e são: a superfície, o brilho e a consistência do tecido formado. Um resultado considerado bom (biologicamente aceitável) teria os cinco parâmetros satisfatórios e um resultado não bom (biologicamente não aceitável) teria um ou mais desses parâmetros não satisfatórios.

\section{2 - Avaliação Histológica}

Após a eutanásia a porção distal do fêmur foi removida em bloco, fixada em formol a 10\%, descalcificada em solução de acido nitrico e formalina e estudada histologicamente. As lâminas foram coradas com Hematoxilina-Eosina. em secções no plano sagital, contendo o longo eixo do fêmur distal para melhor visibilização da extensão do defeito.

\section{4 - Criteria of evaluation}

Specifically for the proposed study, the analysis of two criteria of evaluation was considered: macroscopic and histologic.

\section{1 - Macroscopic evaluation}

Five parameters were analyzed through the macroscopic inspection: the repair concerns the defect cicatrization, the continuity is the levelling and integration of the repair with the adjacent cartilage.

The other three parameters show the external characteristics of the repair and they are the surface, the brightness and the consistency of the tissue formed. A considered good result (biologically acceptable) should present the five satisfactory parameters. On the other hand, a considered not good result (biologically not acceptable) would present one or more of these parameters not satisfactory.

\section{2 - Histologic evaluation}

After the euthanasia the distal portion of femur was removed in block, settled in formol 10\%, decalcificated in solution of nitric acid and formalin and studied histologically. The blades were tinged with Hematoxylin-Eosine. in cuts in the sagittal plan, including the long axle of distal femur for a better view of the extension of the defect.

In the histologic examination of the cuts of distal femur, the attention was particularly directed to the following elements: 1- the type of regenerated tissue in the surface of the defect: cartilage, fibrocartilage or fibrous tissue; 2- the appearance of the cartilaginous surface: smooth, depressed or irregular; 3- presence or absence of the regenerated subchondral bone.

\section{RESULTS}

\section{1 - Macroscopic aspect}

The typical macroscopic aspect in the treated and untreated de- 
No exame histológico das secções do fêmur distal, a atenção foi dirigida particularmente para os seguintes elementos: 1 - o tipo de tecido regenerado na superfície do defeito: cartilagem, fibrocartilagem ou tecido fibroso; 2 - o estado da superfície cartilaginosa: lisa, com depressão ou irregular; 3- presença ou ausência do osso subcondral regenerado.

\section{RESULTADOS}

\section{1 - Aspecto macroscópico}

O típico aspecto macroscópico encontrado nos defeitos tratados e não tratados pode ser visto nas Figuras 3-A e 4-A, resultados considerados bons ou biologicamente aceitáveis. O termo "biologicamente aceitável", segundo Amiel(1) , é utilizado para definir reparos, que à observação macroscópica, se apresentam como tecido neo-formado semelhante à fibrocartilagem, liso, brilhante, firme, em continuidade com a cartilagem adjacente. Trata-se de um critério macroscópico de avaliação, não se podendo estabelecer uma correlação exata com as características histológicas, bioquímicas ou biomecânicas do reparo.

Os dados relativos ao resultado da avaliação macroscópica, que incluiu os cinco parâmetros já citados, estão resumidos nas Tabelas 1 e 2. Observou-se predomínio da formação de um tecido de reparação firme com preenchimento total da lesão, com superfície plana, regular e em continuidade com a cartilagem adjacente nos defeitos tratados. Nos defeitos não tratados essas características foram semelhantes a não ser por apresentarem alterações mínimas da superfície. Porém todos os reparos provenientes de defeitos tratados ou não, foram considerados satisfatórios, portanto biologicamente aceitáveis após doze semanas de evolução.

\section{2 - Aspecto histológico}

A reparação histológica foi considerada satisfatória somente se a superfície do tecido regenerado fosse lisa e coberta por cartilagem e ainda estando no mesmo nível da cartilagem adjacente. As diferenças de tipo de tecido de cicatrização dos reparos foram nítidas.

Para os defeitos tratados a superfície dos reparos mostraram a preservação da cartilagem hialina original lisa, regular e no mesmo nível da cartilagem adjacente hospedeira. A parte profunda do reparo tinha se transformado em tecido ósseo com padrão trabecular próximo da normalidade (Figura 3-B).

A superfície dos reparos provenientes de defeitos não tratados não era regularmente lisa, apresentava pequena depressão e estava

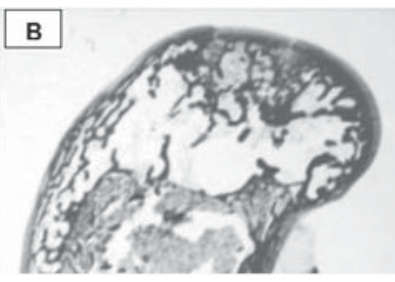

Figura 3 - Defeito tratado: em " $A$ " aspecto macroscópico; em " $B$ " subcondral normal.

gure 3 - Treated defect: in "A": macroscopic aspect; in " $B$ ": healing subchondral bone.
Figura 4 - Defeito não tratado: em "A" aspecto macroscópico; em "B" depressão e osso subcondral desorganizado.

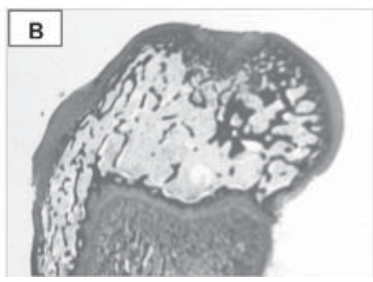

quena

gure 4 - Untreated defect: in " $A$ " macroscopic aspect; in " $B$ " healing with ation of fibrocartilage; surface with little depression and disorganized

\begin{tabular}{|c|c|c|c|c|}
\hline \multirow[t]{3}{*}{$\begin{array}{l}\text { Parâmetros } \\
\text { Parâmeters }\end{array}$} & \multirow{2}{*}{\multicolumn{2}{|c|}{$\begin{array}{c}\text { tratados } \\
\text { treated } \\
\underline{n}=6\end{array}$}} & \multicolumn{2}{|c|}{$\begin{array}{c}\text { náo tratados } \\
\text { untreated }\end{array}$} \\
\hline & & & & \\
\hline & & $\%$ & $\mathbf{n}$ & $\%$ \\
\hline \multicolumn{5}{|c|}{$\begin{array}{c}\text { Reparação do defeito } \\
\text { Defect repair }\end{array}$} \\
\hline $100 \%$ & 20 & 100 & 19 & 95 \\
\hline $75 \%$ & 0 & 0 & 01 & 05 \\
\hline$<75 \%>50 \%$ & 0 & 0 & 00 & 00 \\
\hline$<50 \%$ & 0 & 0 & 00 & 00 \\
\hline \multicolumn{5}{|c|}{$\begin{array}{c}\text { Integração do defeito } \\
\text { Defect integration } \\
\end{array}$} \\
\hline $100 \%$ & 20 & 100 & 19 & 95 \\
\hline $75 \%$ & 0 & 0 & 01 & 05 \\
\hline$<75 \%>50 \%$ & 0 & 0 & 00 & 00 \\
\hline$<50 \%$ & 0 & 0 & 00 & 00 \\
\hline
\end{tabular}

Tabela 1 - Distribuição da freqüência de resultados na avaliação macroscópica da cicatrização dos defeitos.

able 1 - Distribution of the frequency of results in the macrocospic evaluation of defects healing. lage in the treated defects.

fects can be seen in the Figures 3-A and 4-A; the results were considered as good or biologically acceptable. "The biologically acceptable" term, according to Amie/ $\left({ }^{(1)}\right.$, is used to define repairs, that in macroscopical observation, present as neo-formed tissues similar to the fibrocartilage. They are smooth, brilliant, firm, and in continuity with the adjacent cartilage. As this is a macroscopic criterion of evaluation, it is not possible to settle an accurate correlation among the histological, biochemical or biomechanic characteristics of the repair. The relative data to the result of the macroscopic evaluation, that include the five parameters already mentioned, are summarized in Tables 1 and 2. It was observed the predominance of the formation of a firm repair tissue, with total fulfilling of the injury, presenting a plain and regular surface in continuity with the adjacent carti-

In spite of presenting minimum alterations of the surface these characteristics were similar in the treated defects. However, all the repairs of untreated defects or not were considered satisfactory, therefore biologically acceptable after twelve weeks of evolution.

\section{2 - Histologic aspect}

The histologic repair would only be considered satisfactory if the surface of the tissue regenerated smoothly, were covered by cartilage were in the same level of the adjacent cartilage. The differences in the types of cicatrization tissue of the repairs were clear. For the treated defects the surface of the repairs presented the preservation of the smooth, regular original hyaline cartilage and in the same level of the adjacent hostess cartilage. The deep part of the repair became bone tissue with trabecular standard close to normality (Figure 3-B). The surface of the repairs proceeding from treated defects was not regularly smooth. It presented small depression and was predominantly re-covered by fibrous tissue. The deep part presented rudimentarily neoformed trabecular bone. It practically did not present formation of subchondral bone (Figure 4-B).

\section{DISCUSSION}

Not all the cartilaginous injuries are gradual and clinically symptomatic. The articulation can return to its normal state ${ }^{(4,14)}$. The uncertainty about which injury should require surgical repair still remains and it is not sure that the prophylactic treatment would modify for better the particular evolution of each injury. 


\begin{tabular}{|c|c|c|c|c|}
\hline \multirow{3}{*}{$\begin{array}{l}\text { Parâmetros } \\
\text { Parameters } \\
\text { Superfície / Surface }\end{array}$} & \multicolumn{2}{|c|}{$\begin{array}{c}\text { tratados } \\
\text { treated } \\
n=6\end{array}$} & \multicolumn{2}{|c|}{$\begin{array}{c}\text { não tratados } \\
\text { untreated } \\
n=6\end{array}$} \\
\hline & $\mathbf{n}$ & & $\mathbf{n}$ & $\%$ \\
\hline & & & & \\
\hline plana / smooth & 20 & 200 & 17 & 85 \\
\hline depressão / depression & 0 & 0 & 03 & 15 \\
\hline degeneração / degenerated & 0 & 0 & 00 & 00 \\
\hline \multicolumn{5}{|l|}{ Coloração / Color } \\
\hline translúcida / trans/ucide & 19 & 95 & 19 & 95 \\
\hline opaca / opaque & 01 & 05 & 01 & 05 \\
\hline descolorida / descolored & 0 & 0 & 0 & 0 \\
\hline \multicolumn{5}{|l|}{ Erosão / Erosion } \\
\hline nenhuma / none & 20 & 100 & 19 & 95 \\
\hline somente do defeito / only in the defect & 0 & 0 & 01 & 05 \\
\hline defeito e cartilagem adjacente / defect and adjacent cartilage & 0 & 0 & 0 & 0 \\
\hline
\end{tabular}

Tabela 2 - Distribuição da freqüência de resultados na avaliação do aspecto macroscópico dos defeitos.

Table 2 - Distribution of the frequency of results in the evaluation of the macrocospic aspect of the defects.

recoberta por tecido predominantemente fibroso. A parte profunda apresentava osso trabecular neoformado rudimentarmente, não havendo praticamente formação de osso subcondral (Figura 4-B).

\section{DISCUSSÃO}

Nem todas as lesões cartilaginosas são progressivas e nem todas são clinicamente sintomáticas, podendo a articulação retornar ao seu estado normal(4,14). Permanece a dúvida sobre qual lesão necessitaria de reparo cirúrgico e se o tratamento profilático alteraria para melhor a evolução particular de cada lesão.

O coelho foi escolhido, neste estudo, por ser um animal amplamente utilizado em modelos para reparação da superfície articular e a forma cilíndrica do defeito por ser também unanimemente escolhida quando se trata de estudo de cicatrização de lesões focais osteocondrais $^{(9,12,15,16,21,22)}$

Em relação ao tamanho da lesão optamos por criar defeitos de $3.2 \mathrm{~mm} / 4.0 \mathrm{~mm}$ em animais acima de $3.5 \mathrm{~kg}$ de peso para se guardar uma proporcionalidade adequada, pois defeito maiores de $4 \mathrm{~mm}$ de diâmetro já tomam praticamente todo o côndilo femoral medial e de $5 \mathrm{~mm}$ de altura já provocam destruição medular óssea e tais fatores alteram a sensibilidade do modelo experimental e logicamente os resultados esperados(24).

A quantidade de animais envolvidos nesta pesquisa baseou-se em princípios bioéticos, buscando-se utilizar um número mínimo para validação das hipóteses ${ }^{(8,13)}$. Os seis animais da presente série foram selecionados de um grupo maior $(n=20)$ de um estudo mais amplo, justamente por serem todos reparos biologicamente aceitáveis independentemente se eram provindos de defeitos tratados ou não tratados. Todos os joelhos desses 06 animais foram submetidos à ressonância magnética, em um estudo prévio de uma tese de doutorado do autor principal(20). Os exames foram realizados ao final das $1^{\mathrm{a}}, 4^{\mathrm{a}}$, $8^{a}$ e $12^{a}$ semanas de evolução com resultados homogeneamente bons no que diz respeito à cicatrização, porem não no tipo de tecido que se formava na superfície dos reparos. O que se pretendeu no presente modelo animal foi realizar um estudo histológico básico, em uma amostra mínima, homogênea e conhecida, somente para averiguação do tipo de tecido que se formou em ambos tipos de reparos.
The rabbit was chosen, in this study, because it is an animal widely used in repairing models of the articular surface of the defect and the cylindrical form can also be unanimously chosen if the case concerns the study of cicatrization of osteochondral focal injuries ${ }^{(9,12,15,16,21,22)}$.

Regarding the size of the injury we decided to develop defects of $3.2 \mathrm{~mm} / 4.0 \mathrm{~mm}$ in animals over $3.5 \mathrm{~kg}$ of weight in order to maintain an adequate proportionality.

The defects larger than $4 \mathrm{~mm}$ of diameter can practically take all medial femoral condyle. The ones 5-mm height can cause destruction to the bone marrow and such factors modify the sensitivity of the experimental model and the expected result(24).

The amount of involved animals in this research was based on bioethic principles. We used a minimum number for validation of hypothesis ${ }^{(8,13)}$. The six animals of the present series were selected from a bigger group ( $n=20)$ of a wider study, exactly because all the repairs were biologically acceptable independently if they were from treated or untreated defects. All the knees of these 06 animals underwent magnetic resonance, in a previous study of a graduation thesis of the main author ${ }^{(20)}$. The examinations were performed at the end of the $1 \mathrm{st}$, 4 th, 8th and 12th weeks of evolution with homogeneously good results in what concerns the cicatrization, but not to the type of tissue formed on the surface of the repairs. The aim of this present animal model was to perform a basic histologic study, in a minimum sample that was homogeneous and known, in order to verify the type of tissue formed in both types of repairs.

The result of $100 \%$ of biologically acceptable repairs according to the settled macroscopic criteria, the absence of macroscopic alterations in the articular tibia cartilage in contact with the femoral condyles, the absence of infection and the maintenance of the articular stability during the twelve weeks of evolution demonstrated the validity of the experimental method applied. Biologically acceptable repairs can be formed from treated defects or not and can be indistinguishable by the macroscopic appearance. The histologic study allowed us to differentiate both types of repairs. In the circumstances of the histologic study it was well evidenced the type of neoformed tissue for each type of repair. The inferiority of the repairs of treated defects was due to the delay in the formation of the subchondral bone, what shows the basic importance of the subchondral bone in the tissular reorganization. The previsibility of the cartilaginous tissue formation in the treated defects 
A obtenção de $100 \%$ de reparos biologicamente aceitáveis, conforme os critérios macroscópicos estabelecidos, a ausência de alterações macroscópicas na cartilagem articular tibial em contato com os côndilos femorais, a ausência de infecção e a manutenção da estabilidade articular durante as doze semanas de evolução demonstram a validade do método experimental empregado.

Reparos biologicamente aceitáveis podem se formar a partir de defeitos tratados ou não e podem ser indistinguíveis pela aparência macroscópica. O estudo histológico permitiu que se diferenciasse ambos tipos de reparos.

Nas circunstâncias do estudo histológico ficou bem evidenciado o tipo de tecido neoformado para cada tipo de reparo. A inferioridade dos reparos de defeitos não tratados foi devida principalmente ao retardo na formação de osso subcondral, o que mostra a fundamental importância do osso subcondral na reorganização tecidual. A previsibilidade de formação de tecido cartilaginoso nos defeitos tratados e de tecido predominantemente fibroso nos defeitos não tratados estão de acordo com os dados da literatura ${ }^{(10,17,22)}$.

\section{CONCLUSÕES}

Após doze semanas e nas condições experimentais descritas no presente estudo pode-se concluir:

1 - Todos os defeitos osteocondrais tratados e não tratados evoluíram para reparos biologicamente aceitáveis

2 - A análise histológica dos reparos biologicamente aceitáveis demonstrou formação de tecido cartilaginoso nos defeitos tratados e de tecido fibrocartilaginoso nos defeitos não tratados.

\section{REFERÊNCIAS BIBLIOGRÁFICAS}

1. Amiel D, Coutss RD, Abel M, Stewart W, Hailwood F, Akeson W H. Rib perichondrial grafts for the repair of full thickness articular cartilage defects. A morphological and biochemical study in rabbits. J Bone Joint Surg Am 67:911920, 1985.

2. Brittberg M, Nilsson A, Lindahl A, Ohlsson C, Peterson L. Rabbit articular cartilage defects treated with autologous cultured chondrocytes. Clin Orthop 326:270-283, 1996

3. Calandruccio RA, Gilmer WS Jr. Proliferation, regeneration, and repair of articular cartilage of immature animals. J Bone Joint Surg Am 44:431-455, 1962.

4. Campbell CJ. The healing of cartilage deffects. Clin Orthop 64:45-63, 1969.

5. Convery FR, Akeson WH, Keown GH. The repair of large osteochondral defects: an experimental study in horses. Clin Orthop 82:253-262, 1972.

6. De Palma AF, McKeever CD, Subin DK. Process of repair of articular cartilage demonstrated by histology and autoradiography with tritiated thymidine. Clin Orthop 48:229-242, 1966.

7. Fuller JA, Ghadially FN. Ultrastructural observation on surgically produced partial-thickness defectes in articular cartilage. Clin Orthop 86:193-205, 1972.

8. Gomes PF. Curso de estatística experimental. 2.ed. São Paulo: Universidade de São Paulo, 1963. p.53-60

9. Hangody L, Kish G, Karpati Z, Eberhart R. Osteochondral plugs: autogenous osteochondral mosaicplasty for the treatment of focal chondral and osteochondral articular defects. Oper Tech Orthop 7:312, 1997.

10. Hangody L, Feczkó P, Bartha L, Bodó G, Kish G. Mosaicplasty for the treatment of articular defects of the knee and ankle. Clin Orthop 391(Suppl):328-336 2001.

11. Key J. Experimental arthritis: the changes in joints produced by creating defects in the articular cartilage. J Bone Joint Surg Am 13:725, 1931.

12. Kim HK, Moran ME, Salter RB. The potential for regeneration of articular cartilage in defects created by chondral shaving and subchondral abrasion. An experimental investigation in rabbits. J Bone Joint Surg Am 73:1301-1315, 1991.

13. Leopizzi N, Bollinger Neto R, Barros Filho TEP, Azze RJ. Modelos experimentais em Ortopedia e ISSO 10993: "Biological evaluation of medical devices- Part and the fibrous tissue in the untreated defects is in accordance with the literature data(10,17,22).

\section{CONCLUSIONS}

After twelve weeks under the described experimental conditions in the present study, we can conclude.

1 - All the treated and untreated osteochondral defects became biologically acceptable repairs.

2 - histologic analysis of the biologically acceptable repairs demonstrated cartilaginous tissue and fibrocartilaginous tissue formation in the treated or untreated defects respectively.
2: Animal welfare requirements" Interpretação e extensão da norma. Acta Ortop Bras 6:139-142, 1998.

14. Mankin HJ. Current concepts review. The response of articular cartilage to mechanical injury. J Bone Joint Surg Am 64:460-466, 1982.

15. Mankin HJ. Localization of tritiated thymidine in articular cartilage of rabbits II: Repair in immature cartilage. J Bone Joint Surg Am 44:688-698, 1962.

16. Meachin G, Roberts C. Repair of joint surface from subarticular tissue in the rabbit knee. J Anat 109:317-327, 1971

17. O'Driscoll SW, Keeley FW, Salter RB. The chondrogenic potential of free autogenous periosteal grafts for biological resurfacing of major full-thickness in joint surfaces under the influence of continuous passive motion. An experimental investigation in the rabbit. J Bone Joint Surg Am 68:1017-1035, 1986.

18. Peterson L, Minas T, Brittberg M, Nilsson A, Stogren-Jansson E, Lindahl A Two to nine years outcome after autologous chondrocyte transplantation of the knee. Clin Orthop 374:212-234, 2000.

19. Pridie $\mathrm{KH}$. A method of resurfacing osteoarthritis knee joints. In: Proceedings of the British Orhopaedic Association. J Bone Joint Surg Br 41:618-619, 1959

20. Ribeiro JL. Estudo comparativo da cicatrização de defeito osteocondral em coelhos. São Paulo, 2003. Tese (Doutorado), Faculdade de Medicina da Universidade de São Paulo.

21. Rubak JM, Poussa M, Ritsilä V. Chondrogenesis in repair of articular cartilage defects by free periosteal grafts in rabbits. Acta Orthop Scand 53:181-186 1982.

22. Salter RB, Simmonds DF, Malcom BW, Rumble DJ, MacMichael D, Clements ND. The biological effect of continuous passive motion on the healing of ful thickness defects on articular cartilage. An experimental investigation in the rabbits. J Bone Joint Surg Am 62:1232-1251, 1980

23. Steadman JR, Rodkey WG, Briggs KK, Singleton SB. Microfracture technique for full thickness chondral defects: technique and clinical results. Oper Tech Orthop 7:300-304, 1997

24. Wakitani S, Goto T, Pineda SJ, Young RG, Mansour JM, Caplan AJ, Golberg VM. Mesenchymal cell-based repair of large full-thickness defects of articular cartilage. J Bone Joint Surg Am 76:579-592, 1994. 